This item was submitted to Loughborough's Research Repository by the author.

Items in Figshare are protected by copyright, with all rights reserved, unless otherwise indicated.

\title{
Theorising global modernity: descriptive and normative universalism
}

PLEASE CITE THE PUBLISHED VERSION

https://www.routledge.com/Legitimization-in-World-Society/Mascareno-Araujo/p/book/9781409440888

PUBLISHER

Ashgate (now Routledge, Taylor \& Francis Group)

VERSION

SMUR (Submitted Manuscript Under Review)

\section{PUBLISHER STATEMENT}

This work is made available according to the conditions of the Creative Commons Attribution-NonCommercialNoDerivatives 4.0 International (CC BY-NC-ND 4.0) licence. Full details of this licence are available at: https://creativecommons.org/licenses/by-nc-nd/4.0/

\section{LICENCE}

CC BY-NC-ND 4.0

\section{REPOSITORY RECORD}

Chernilo, Daniel. 2019. "Theorising Global Modernity: Descriptive and Normative Universalism”. figshare. https://hdl.handle.net/2134/23267. 


\title{
Theorising Global Modernity: Descriptive and Normative Universalism
}

(forthcoming in Legitimization in World Society, Araujo, K. and Mascareño, A. (eds), Ashgate)

\author{
Daniel Chernilo \\ Loughborough University
}

Diagnoses over the truly global nature of major economic, ecological or technological trends are now widely available across humanities and social sciences. They may account for the rise of 'the global' as something recent or coeval with the rise of modernity itself, emphasise the prevalence of technological, cultural, economic or institutional patters of change, favour a flat or a more layered understanding of the global and indeed refer to the normative consequences of these processes optimistically or pessimistically. Yet in all cases theorising 'the global' has become a major theme of our social-scientific Zeitgeist (Bauman 1998, Beck 2000, Castells 1996).

A question that remains in this context is the relationship between 'the global' in theories of global modernity and the need to uphold or criticise their universalistic presuppositions. The current mood in contemporary social theory is clear: from postmodernism to pragmatism, from postcolonialism and subaltern studies to cultural studies, universalism has been the subject of a sustained demolition exercise: historically as undue or even lazy generalisation, conceptually as reification of the particular, normatively as ideological power (Rorty 2006, Connell 2007). The main theoretical problem of this sceptic position is that the global cannot be accounted for through a potentially endless survey in cultural difference and specificity. I should instead like to contend that questions about universalism are bound to remain when theorising the global both in terms of truly worldwide real-time interaction across geographical and cultural continents and as legal and institutional developments that transcend traditional national barriers. My goal in this paper is to try to explicate the kind of universalistic commitments that are built into theorising the global modernity; and my main argument shall be that in order to conceptualise the global we need to reflect on both the descriptive and normative sides of universalism.

More concretely, I concentrate on a sociological argument that in different versions can be found throughout the sociological tradition; namely, the idea that differentiation processes constitute are central in the constitution of modern society. The most salient of its contemporary expressions, that of Niklas Luhmann, is a good case in point because it is committed to the separation of descriptive and normative standpoints: its key notion for understanding the global, that of 'world society', is introduced and justified as a result of the emergent status of communication and is expected to operate with independence from normative considerations. But below I should like to argue that an explicit commitment to descriptive universalism, the ideas of the autonomy of the social and the globe as a single place, only works because it implicitly subscribes to normative universalism - a universalistic idea of humanity and individual human beings who share 'universal human traits'. ${ }^{1}$ In turn, normative notions of universalism need to be accounted for vis-à-vis their natural law heritage.

Let me then set the tone of my enquiry by quoting from a relatively a recent article on current challenges in international theory by Finnish legal theorist Martti Koskenniemi. He claims that over the past two decades or so new concepts and theories have emerged to make sense of

\footnotetext{
1 The attempt to connect the 'descriptive' universalistic orientation of functional approaches with normative questions - even if the latter are not conceived in terms of universalism - is not altogether original (Fischer-Lescano 2012, Mascareño and Chernilo 2009, Mouzelis 1999).
} 
current transformations in international life. He mentions apparently 'technical' expressions like 'regulation' or 'governance' but argues that rather than taking at face value their claim to novelty, this is a 'change in language' that needs to be analysed vis-à-vis

an analogous moment in the late $17^{\text {th }}$ century. Then as now, a new empirically 'realist' language (natural law/international relations) emerged to give voice to new preferences, forms of authority and hierarchy of influence. The new vocabulary — a new natural law - gives voice to special interests in functionally diversified regimes of global governance and control. This feeds on the habit of international lawyers to articulate the founding certainties of the profession in sociological, instrumental terms. The new orientation takes these articulations seriously and, like the $17^{\text {th }}$ century ius naturae et gentium, builds on a state of nature that it abstracts from observation of human beings as they are now. In the most sophisticated form available, the state of nature is articulated today in the anarchy of autonomous functional systems: trade, human rights, environment, security, diplomacy, and so on. Because there is no truth superior to that provided by each of such system or vocabulary, each will recreate within itself the sovereignty lost from the nation-state. (Koskenniemi 2009: 411, my italics)

This long passage is illuminating because it explicitly links contemporary ways of theorising the global as processes of social or functional differentiation with its philosophical and ultimately normative presuppositions. Koskenniemi's main insight, which I shall use below as a strategy to reassess the relationships between descriptive and normative universalism, is that current global processes that we describe in terms of functional differentiation need to be connected back to intellectual and socio-historical developments in the seventeenth century. On the one hand, there are questions about the status of arguments on the differentiation of modern society: is differentiation a general framework for the understanding of social life as such or is it rather a result or conclusion of the changing nature of global processes. On the other hand, there is the question of the philosophical underpinnings and normative presuppositions that are built into differentiation theory. In what follows, I should like to deal with each side of argument. First, I examine the status of differentiation arguments in classical and contemporary social theory and unpack its descriptive universalism. Secondly, I assess the extent to which differentiation arguments also require some kind of normative universalism that is never fully decoupled from modern natural law.

\section{Descriptive universalism and the sociology of social differentiation}

Since Talcott Parsons (1968) published The Structure of Social Action in 1937, one extremely influential way of looking at conceptual developments within sociology points towards the development of a unified theoretical framework as its most desirable goal. Regardless of their substantive differences and clashing epistemic foundations, Marxists and functionalist approaches alike seem to have taken a leading voice in advancing a strict separation between the history of sociology, on the one hand, and systematic theory building proper, on the other. In relation to contemporary theories of the global, an example of this can be said to be taking place within current International Relations theory. In the Marxist camp, Justin Rosenberg has forcefully made the argument that a new social theory of the international need to be established on the basis of classical social theory's fundamental blind spot: "while Classical Social Theory provides enormous resources for enriching international theory (...) nowhere do we find it taking intellectual possession of those concerns themselves. Quite simply, there is no classical sociological theory of 'the international'” (Rosenberg 2006: 312). 
The kind of theoretical framework that is required, he argues, can be firmly established in relation to Trotsky's notion of 'combined and uneven development'. Whereas he finds the whole canon of social theory problematic due to its complete neglect of the international, Trostky alone would do to remedy such a shortcoming (Rosenberg 2005, 2010). ${ }^{2}$ Within functionalism, Mathias Albert $(2007,2009)$ argues that proposition of adopting a number of key insights of Luhmann's sociological theory. Albert's claim is less whether a unified theory of globalisation is to be established exclusively on Luhmannian terms and, more substantively, that we ought to accept the centrality of differentiation (and rationalisation) processes in characterising current world society. To an important extent this was Luhmann's own position; not least in relation to his wider scepticism towards the usefulness of systematically engaging with the works of classical sociology as something that does not fall within the field of theory-building (Luhmann 1994). ${ }^{3}$ But Albert offers an additional argument on this connection as he speaks in favour of decoupling questions of social theory's reliance on nationalistic preconceptions from issues of normative integration more broadly understood. We ought to pay more attention to the latter, he argues, as they are the ones that are really preventing us to grasp the novelty behind recent globalising trends because "both theoretically as well as empirically forms of normative integration do not seem to be sustainable if one indeed accepts that it makes sense at all to talk about society at a comprehensive 'world' scale" (Albert 2009: 127). Although I am interested more in their approach to the history of social theory than in their substantive claims on social life itself, Rosenberg and Albert's claims are of interest because they highlight two key facts of the history of modern social theory. On the one hand, that the project of a 'unified theory of the social' has been and remains central to the way in which social theory tries to conceptualise the world; on the other hand, that such an endeavour has always been met with stern resistance and they are ever more unlikely to go away. Differently put, there is a fundamental tension between social theory's claim to universalism and their necessary dependence to particular socio-historical contexts and intellectual influences. General social theory is, or needs to be, philosophically informed while remaining committed to the empirical understanding of modern social trends.

A good place to start this reconstruction is the distinction between 'community' (Gemeinschaft) and 'society' (Gesellschaft), which is surely one of the key constitutive motives not only of the foundational period of sociology but also of modernist (Bendix 1967) and even of a great deal of contemporary writers (Chernilo 2007). It has arguably never been fully clear whether the distinction is being intended in fundamentally historical terms - and thence the temporality of modernity becomes constituted by the actual transition that makes the former obsolete and brings about the latter - or whether the emphasis is in fact more analytical — and

\footnotetext{
${ }^{2}$ Rosenberg (2005) echoes almost by the word the kind of criticisms to classical sociology put forward by the same globalisation theorists he has so duly, and vehemently, criticised (Rosenmberg 2005). The problem lies, in my view, in the methodological way in which he finds the whole canon of social theory at fault (Montesquieu, Rousseau, Smith, Condorcet, Malthus, Saint-Simon, Comte, Tocqueville, Marx, Mill, Spencer, Tönnies, Weber, Durkheim, Pareto and Simmel) only to give later all the credit to a single towering figure -in his case, Leon Trotsky (Rosenberg 2006: 336-7). There is something troublingly fascinating indeed in this obsession to criticise classical social theory for having had no theory of the national (Smith 1983), the nation-state (Wimmer and Schiller 2002), the international (Rosenberg 2006), the global (Shaw 2000, Scholte 2000) or the cosmopolitan (Beck 2006).

${ }^{3}$ It is Luhmann's (1977) own highly original and consequential revisiting of Parsons' theory of generalised symbolic media that I believe disproves that kind of scepticism towards critically engaging with previous theories of society (Chernilo 2002). I am therefore more sympathetic to the softer formulation of transversal research programmes that cut across traditional paradigmatic frameworks.
} 
thus the issues at stake have more to do with the structural conformation of modern social life per se. ${ }^{4}$ In its 'canonical' though somewhat forgotten formulation, Ferdinand Tönnies introduces it as follows:

Gesellschaft takes as its starting point a group of people who, as in Gemeinschaft, live peacefully alongside one another, but in this case without being essentially united - indeed, on the contrary, they are here essentially detached. In Gemeinschaft they stay together in spite of everything that separates them; in Gesellschaft they remain separate in spite of everything that unites them (...) Nothing happens in Gesellschaft that is more important for the individual's wider group than it is for himself. On the contrary, everyone is out for himself alone and living in a state of tension against everyone else (...) Such a negative attitude is (...) characteristic of Gesellschaft at any given moment in time. (Tönnies 2001: 52)

He thus associates society to such processes and trends as instrumental rationality, contracts, novelty, business, science and public opinion, masculinity, urban centres, national and international life, individualism and state bureaucracy. Community is in turn characterised by their opposite expressive rationality, custom, the old and enduring, religion and tradition, femininity, local villages, collectivism and the nation. Indeed, central to Tönnies' formulation is the fact that while empirical societal tendencies were becoming more and more important, his unmistaken normative preferences lie in communal life. Only partially aware of Tonnies' arguments, Durkheim's (1984) own rendition of the distinction between the old and the new, the homogeneous and the differentiated, is found in Division of Labour in Society. He effectively equated modernity with the rise of social differentiation, which created a new 'organic' form of social solidarity that came to replace the old forms of mechanic solidarity that was found within societies with very low degrees of division of labour. A few generations later, Talcott Parsons fully understood the importance if the distinction but thought that in order to rescue its sociological centrality it was only viable in analytical terms. Societal and communal elements both remain of relevance in modernity:

I should like to suggest, therefore, a refinement of Durkheim's classification. If organic solidarity and mechanical solidarity are correlative terms, one should refer to the type of solidarity which focuses on the legitimation of political institutions, and the other to that type which focuses on economic institutions. Broadly speaking, we may say that, although the situation varies substantially with the type of social structure, both exist simultaneously in parts of the same social system, parts that can be distinguished on the basis of structure and through analysis; and there should be no general tendency for one to replace the other. (Parsons 1967a: 24, my italics)

All Gesellschaft-like concepts such as division of labour, solidarity, bureaucracy, valuespheres and so on are equally based upon some notion of differentiation: however defined, strong notions of society presuppose that the old unifying centres of social relations are rapidly dissolving and that newer forms of social order exist thanks to different rationalities whose congruence can no longer be presupposed in principle nor indeed oriented in full. Rather than keep focusing on some kind of 'before/after' distinction, classifications of modernity into periods, regions or structural trends must concentrate on playing continuities and discontinuities, similarities and dissimilarities, against each other. In contemporary social theory, however, Gemeinschaft/Gesellschaft is being systematically reintroduced in temporal rather than analytical

\footnotetext{
${ }^{4}$ It is the conflation of these two planes that led Bernard Yack (1997) to make the claim of social theory's fetishism of modernity. While sympathetic to his criticism, I do not want to throw the baby with the bath water so I shall seek for a reformulation of the difficulty rather than for its abandonment.
} 
terms: early/late modernity; first/second modernity; linear/second modernity, industrial/postindustrial/information society, and indeed tradition/modernity/postmodernity. We should avoid the use conceptualisations that are based on —alleged as well as real- historical breaks because they make all the harder to look at the development of modern social relations in terms of a constant movement of continuities and discontinuities. That, in my view, is a strong argument in favour of a strong notion of modern world society in both historical and analytical terms.

We can then see that the problem of social or functional differentiation is as old as sociology itself; the understanding of modern societies in terms of processes of social differentiation has always been at the core of sociological interpretations on the rise of modernity. In the early functionalist tradition, represented by Herbert Spencer (1961) and Emile Durkheim, the concept of differentiation is utilised quite explicitly as they found in it extremely high explanatory potential in terms of evolutionary processes as well as integrative consequences. Indeed, still in the period of classical sociology we also find it outside the functionalist tradition, for example, in Georg Simmel's (1909) discussion on the processes of group formation as well as in Max Weber's understanding of the processes of social and cultural rationalization in his famous intermediate reflections on the differentiation of value spheres and the tragedy of modern culture (Weber 1970, Schluchter 1981). In classical sociology, then, differentiation processes are posed in terms of historical or evolutionary trends; the diagnosis is presented as an empirical account of long-term and deep-seated trends that have given modern society its actual structural shape. For differentiation theorems to be found sociologically relevant, their intellectual worth is to be descriptive/explanatory rather than foundational or philosophical and while their immediate scope may or may not have been the internal differentiation national economies, the ultimate unit of analysis was undoubtedly the worldwide development of modernity. In post-war sociology, Talcott Parsons and Niklas Luhmann did of course make a great deal of questions of differentiation, but it is arguably the case that differentiation is equally central to the critical theories of Jürgen Habermas $(1984,1987,1996)$ - the differentiation between functional systems and the lifeworld, the internal differentiation of normative structures within modern lifeworlds, the cognitive differentiation between philosophical and scientific knowledge, the normative differentiation between morality and legality — and Pierre Bourdieu (1977) — through his theories of different fields and types of capital.

Yet the very salience of arguments on differentiation within sociology, on the one hand, and the level of generality at which they are supposed to work, on the other, may be signalling their strong philosophical status as a key underpinning of sociological analysis — not least, because a legitimate field of sociological enquiry is defined insofar as it points towards understanding processes of differentiation. There are at least five different propositions here and in combining them it becomes easier to realise the quasi-transcendental status of differentiation arguments within sociology.

(a) Differentiation is one of those evolutionary universals of organic life that connects human and non-human processes (Parsons 1961, 1967b). More concretely, in terms of modern sociology differentiation points towards a dynamic feature, if not of social life as such, at least of modern social life according to which there is an immanent tendency towards specialisation.

(b) It is the very logic of differentiation, rather than the number of already differentiated subsystems, what is found important in most general sociological theories. The 
substantive nature of the process may be diverse in terms of epistemological foundations or political implications, but the centrality of the logic of differentiation is hardly ever in doubt.

(c) The notion of differentiation delineates, in a non-conventional manner, an ontological realm that we can properly refer to as 'the social': differentiation processes are inextricably related to the theorem of the emergence of the social. This is a nonconventional argument because the actual existence of such a realm can never be put in doubt if the sociological enterprise is to remain meaningful.

(d) All functionally differentiated systems operate under a principle a full inclusion (Stichweh 2008). All human beings can have access to systemic provisions with no further exceptions than those that inhere in the functioning of the systems themselves. Within the context of modern world society, moreover, it can unproblematically be accepted that these systems' operations have finally achieved worldwide reach.

(e) Sociological notions of differentiation make increasingly hard to speak of social life as having any kind of normative or integrative centre that can hold society together. Modern society has no centre and there is no master rationality in society. The sociological idea of modern society was established in the view that integration was always problematic and tentative rather than already given. ${ }^{5}$

For all its claims to sociological innovation and getting sociology at last on a firm theoretical footing, Luhmann's case on the centrality of differentiation is consistent with these five propositions. He takes the global very seriously indeed:

there exists today only one society on earth: the world society. The environment of this one global society cannot consist of other human society, and it can no longer be marked by territorial frontiers (...) If we are unbiased in our observation, the emergence of a new global system of world society appears as an undeniable fact. This requires corresponding changes in the concept of society. (Luhmann 1977: 526-7)

World society then refers to endless communicative possibilities, communication as horizon of possibilities in which communication itself is the aspect that constitutes the social. The world aspect of the world society has nothing to do with a geographical reference to the globe as a whole but rather points to the limitless growing of communicative possibilities that the rise of functional differentiation brings with it. It refers to an infinite horizon of meaning within which the functional differentiation of subsystems is always expanding and finding new ambits. The world society is defined as an open horizon within which social relations based on meaning can endlessly unfold: "The world society is the self-occurrence of the world within communication" (Luhmann 1997: 150). Therefore, his idea of the world does not refer to any concrete entity that holds individuals and things within it. Rather, the world is more aptly defined as an endless horizon of possible meanings (Luhmann 1997: 153). The self-referential nature of the world

\footnotetext{
${ }^{5}$ To be sure, arguments have been made that not all societal spheres hold the same dignity — for instance, in the very particular role Weber (1970) attributed to politics and religion within his broader diagnosis of the tragedy of modern culture - and thence some may be said to be 'more important' than other. But the argument can be made that even in Marx's own account on the primacy of the reproduction of material life, primacy means neither strict derivation nor centrality (Fine 2002).
} 
society is based upon the assumption that meaning always 'refers to further meaning' so that it forms a closed system that, 'in its unity', can only be apprehended

As the ultimate horizon of all meaning: as the world. Consequently, the world has the same inevitability and unnegatability as meaning. Any attempt to go beyond it conceptually only extends it; any such attempt would have to enlist meaning and the world and this would be that it was trying not to be. (Luhmann 1995: 69)

Luhmann's idea of the world society is therefore social because it points to the simultaneous self-referential, all-inclusive and endless nature of meaning: all meaningful relations take place within meaning only within it; world society knows of no other limits than those thus far achieved by the ever-growing expansion of communication. But it is of course also social because it refers to communication as the only one element that is able to encompass all the features that make society an emergent reality: social life understood as continuous, improbable and meaningful. In Luhmann's (1990: 178) own words: 'modern society is, therefore, a world society in a double sense. It provides one world for one system; and it integrates all world horizons as horizons of one communicative system (...) a plurality of possible worlds has become inconceivable. The worldwide communicative system constitutes one world that includes all possibilities'. Even if others have also emphasised that it is only in modernity that one can speak of the world society, it is Luhmann who has made the connection between differentiation process and world society point and thus constructed on the basis of descriptive universalism. Differentiation processes are surely a central structural process of modernity but its appropriate conceptualisation requires us to move beyond 'differentiational reductionism' (Robertson 2009) - to understanding social life as such as uniquely devoted to the enhancement of the logic of differentiation. The centrality of differentiation process does not warrant treating it in terms of primacy.

\section{Normative universalism or the return of natural law}

At one level, the question for us to discuss in this section is the general one on the relationships between description and normative in social scientific enquiry. But here I will only explore how the tension between both planes appears to work in the context of this particular research programme in sociology. Theories of functional differentiation are interesting in this content for two reasons: first, they have an unrelenting commitment to descriptive universalism (world society encompassing the whole world and being the result of the emergent status of communication); secondly, they argue that descriptive universalism has no need of normative underpinnings. What we now have to do is to assess whether the decisive descriptive thrust of sociological arguments on functional differentiation require normative presuppositions or carry normative implications that cannot be fully accounted for. I plan to carry out this assessment by looking into the natural-law background of differentiation arguments.

Indeed, as an intellectual tradition, natural law belongs to no particular philosophical current and has thus been referred to as a key part of the Western intellectual canon (Glacken 1967, Tuck 1981) from the time of Stoicism and Roman Law (d'Entrèves 1970), and it has also been connected to other Ancient cosmologies (Voegelin 1962). Besides, natural law presuppositions have been found in all variants of modern catholic (Rommen 1998), liberal (Haakonssen 1996, Schneewind 1998), conservative (Gierke 1927), Marxist (Bloch 1996) republican (Arendt 1958, Bohman 2004, Skinner 1998), critical legal studies (Douzinas 2000) and cosmopolitan (Fine 2007, Habermas 2001) ways of thinking. In all cases, the problem of 
universalism has been the most salient intellectual concern of natural law theory. More precisely, natural law has centred on normative universalism: the idea that universal moral norms are valid not on the basis of our particular features in terms of class, gender, religion or ethnicity but because of our shared belonging to the human species. ${ }^{6}$

Modern social theory thus differs from traditional natural law to the extent that its primary focus lies more, as we have just seen, on descriptive universalism: the rise and global expansion of modernity. But in order to account fully for this difference between normative and descriptive universalism we must equally acknowledge the extent to which modern social theory emerged from and remains rooted in the natural law tradition. Normative and descriptive universalism are different and I am not arguing here that they ought to be equated. But I do think that their relationships have not been adequately conceptualised, on the one hand, nor have we explored the extent to which that they depend on each other, on the other hand. There are at least three aspects that speak in favour of exploring further these connections.

(a) There is the question of how to engage with the critique of the fundamental presuppositions of one's predecessors. A key intellectual drive of the sociological programme on functional differentiation is that its explanatory account of the emergence and main features of modernity is predicated upon the idea of dispelling metaphysical illusions. Indeed, this is a theme running through all writers of the classical period, from Comte to Weber, and is a motif that twentiethcentury sociology definitively inherited. Interestingly, the critique of one's predecessors tended to concentrate on their presuppositional shortcomings while the required remedies were articulated in more methodological terms. Thus, Durkheim's (1982) rules of the sociological method were expected to help overcome previous ontological inadequacies in the conceptualisation of social facts, Marx's historical materialism sought to revise in one combined critique Scottish political economy, neo-Hegelianism and Rousseauian political philosophy and Weber's $(1949,1975)$ critique of both historicism and positivism was to be overcome via idealtypes. Indeed, Luhmman's own criticism of what he refers to as the excessive normativism of the 'old-European' tradition, or of the separation between subject and object, is based on the methodological re-articulation of observations of first- and second-order. And yet this is exactly how Hobbes' (1996) secular critique of traditional natural law sought to break free Grotius and Puffendorf's religious conceptions of human nature in terms of 'natural sociability', how Rousseau (1993) criticised Hobbes' depiction of 'natural' individualism as derivative rather than truly natural, how Kant $(1996,1997)$ accused both Hobbes and Rousseau of metaphysics in their derivation of human nature from a wholly imaginary 'depiction' of the state of nature, and how Hegel (1995) read Hobbes and Rousseau's 'positivism', on the one hand, and Kant's 'idealism', on the other, as truly two sides of the same coin because in both cases there was an ideal state of affairs that was first constructed and then reified instead of having concentrated on the actual understanding of social life. What modern social theory still takes to be one of its inspiring insights, the belief in the need of a clean slate, is in fact central to the development of modern natural law. ${ }^{7}$ When it comes to this way of justifying a claim to novelty or originality, sociology works in the shadow of the old adage 'the more it changes, the more it remains the same'.

\footnotetext{
${ }^{6}$ Full justification for what follows in Chernilo (2013a).

${ }^{7}$ Over the past fifty years this claim has been repeated again and again by such salient figures as Anthony Giddens (1993), Pierre Bourdieu (1993), Alain Touraine (1977), Bruno Latour (2000) and indeed Luhmann himself. Although this is something I cannot fully explore here, it is worthy of note that this claim to novelty is not echoed by Jürgen Habermas, whose work is arguably closer and acknowledges a greater to natural law than the sociologists mentioned above (Chernilo 2013b).
} 
(b) More substantively, the centrality of the idea of differentiation to the sociological imagination is already a direct heritage from the natural law tradition. Arguments on differentiation play as big a role in sociological accounts of the rise and main features of modernity as they did in the natural law writers from which the sociological tradition emerged although it sought it had left definitively behind: Montesquieu's (1990) theory of the division of power in The Spirits of the Law, Adam Smith's (1974) argument on the division of labour as central to progress and modernity in the first three books of The Wealth of Nations, Marx and Engel's (1974) comments on the division of labour in the opening sections of The German Ideology, Kant's (1997) separation between legality and morality in the Metaphysics of Morals and indeed Hegel's (1991) arguments differentiation between the state and civil society, on the one hand, and then on the internal differentiation of civil society itself, on the other, that constitute the bulk of his Philosophy of Right. In all cases, modern natural law was already aware of the need for descriptive and normative arguments to remain specific but work together: the differentiation of social spheres was simultaneously introduced as the description of an empirical trend and as the mostly positive outcome of sociohistorical trends whose desirability was secured by some combination of nature, history and progress.

(c) The key sociological theorem on the transition of between community and society is constructed taking as implicit model one of the most central tenets of modern natural law: the transition from the state of nature to the civil condition. The dependence of 'community/society' from 'state of nature/civil condition' is most apparent in Tönnies' (2001) explicit acknowledgement of intellectual sources, but can also be seen in Marx's (1975) discussion of alienation in the 1844 Manuscripts and in Durkheim's (1965) systematic recourse to the state of nature throughout Elementary Forms of Religious Life. To be sure, for both natural law and social theory there is a tension between the partly historical and partly analytical grounds on which the distinction is justified. For natural law, the state of nature is that condition within which human beings live in isolation from one another and which, although it is consistent with individual human nature, it prevents the full realisation of our human potentials. A fully human life is only possible as we leave the state of nature and start living alongside other human beings. Classical social theory departs from natural law in that it sees both community and society as inextricably social, but it follows natural law in how it understands that transition as inevitable and fundamentally connected to the realisation of our human potentials in society.

These are all general and admittedly contentious propositions so let me know make a more detailed case in relation to Luhmann. To be sure, natural law does not figure centrally in his work, but to the extent that he did refer to it he argued, along conventional sociological grounds, that 'nothing results from the historically deducible meaning of natural law' because, "natural law remains only as an empty shell of a word, applicable in flowery phrases" (Luhmann 2008: 24). Indeed, whereas above I argued that an explicit universalistic orientation is central to natural law as an intellectual tradition, Luhmann's (2008: 25) view remains, however, that natural law 'correlate(s) with the immanent imperative of a noble society, thus with the imperative of stratified differentiation'. ${ }^{8}$ It is then wholly consistent that, as the same time as he rejects 'human

\footnotetext{
${ }^{8}$ On this he is closer to Gierke (1927), who in turn is the only writer mentioned above who does not see the universalistic orientation of natural law as its central tenet. See Fine (2002) for a similar argument on the transition from traditional to modern natural law and Kessler (2009) for a discussion of the insufficiencies of natural-law presuppositions in contemporary international relations from a Luhmannian perspective.
} 
rights' as a-historical, 'naturalistic' and indeed a residue of old-European thinking, Luhmann favours an idea of 'fundamental rights' that can help secure the differentiation of society — most notably vis-à-vis the temptation of political centralisation (Luhmann 2010: 99-101). In other words, while human rights cohere on a fallacious anthropologism that no longer can be said to work, fundamental rights are a wholly social institution whose main function is to contribute to the furthering of functional differentiation: fundamental rights are both empirically real and normative desirable. Indeed, it is equally also interesting that when having to answer directly the question of the possibility of indispensable norms in modern society, the argument is nonetheless put thus:

it is advisable to limit the discussion of human rights to the problems of injury to human dignity (...) Of injuries to human rights, experienced globally in a unified manner, one can speak only of unambiguously unacceptable occurrences, when the weighing of pros and cons is no longer an option, and at best an understanding for tragic choices may still be expected. Injustice, in any case. (Luhmann 2008: 34, my italics)

The formulation is remarkable. First, because the connection Luhmann makes between human rights as injuries to human dignity is extremely close to some of the most conventional natural-law formulations he had just discarded. ${ }^{9}$ Secondly, because Luhmann introduces a strong universalistic clause in that the injuries he has in mind have to be universally experienced (i.e. globally and unanimously) as negative. Thirdly because he uses throughout the text the language of tragic choices which of course resembles Weber and Simmel's diagnosis of the differentiation of values spheres as the constitutive of modern culture. My argument here is that even in Luhmann's case, as he goes deeper in exploring the normative constitution of modern society from an allegedly non-normative point of view, a great deal of social theory's intellectual worth actually lies in the way in which it is able to recast natural law normative universalism in terms and under conditions that are acceptable to our modern experiences and ways of life. To be sure, this is neither an explicit attempt to rescue of natural law nor has social theory an interest in natural law for natural law's own sake. It is rather the consequence of seriously attempting to describe social processes that however can only be fully addressed through a normative language: what does human justice consists of, what is the social element of modern social relations, is it possible (and how) to justify rationally our cognitive and normative propositions.

In other words, insofar as a strong conception of humanity universalitically framed is the key presupposition social theory inherits from the natural-law tradition, descriptive and normative statements can and must be clearly distinguished but may be bound to remain intertwined. I should like to argue that we can hardly practice sociology and look at the development of modern international relations without a strong conception of humanity as a single species, a conception which is never completely independent from natural law presuppositions. The twin analytical propositions out of which social theory was born, sociocultural variation and the social as an emergent realm counterfactually presuppose that there are human beings in action, that they are the ones who can always do differently, and that their actions are bound to become autonomous from whatever motives and intentions they originally came from. ${ }^{10}$

\footnotetext{
${ }^{9}$ Not least, again, within the Marxist tradition, as in Ernst Bloch's (1996) Natural Law and Human Dignity.

${ }^{10}$ I am wholly in favour of the cosmopolitan project as understood by Jürgen Habermas (1998, 2001), Hauke Burnkhorst (2005), Robert Fine (2007) or Bryan Turner (2006a, 2006b) — see Chernilo (2012a, $2012 b$ ). But in this context, rather than speaking in favour of global solidarity or world citizenship, my
} 
All individual human beings are to be regarded as endowed with some universal attributes that make them able to create and recreate social life (although, of course, never at their own will). A list of these attributes will of course be different in different sociological outlooks, but in using Luhmann's threefold division of meaning into its objective, temporal and social dimensions, the following attributes can be provisionally mentioned:

(a) within the objective dimension: (1) the satisfaction of bodily needs and (2) a sense of coupling with the outer world including that with one's own species;

(b) within the temporal dimension: (3) a sense of self-identity and (4) a sense of communal identity, both of which must show a degree of continuity over time

(c) within the social dimension: (5) rational for devising courses of action, (6) creative thinking in imagining alternative worlds, (7) emotions and (8) language. ${ }^{11}$

It is by no means my intention to argue that social theory's claim to universalism is based on transcendental normative standpoints that, as in traditional natural law, sought to look at the social world from above and the outside. Nor do I contend that some kind of deduction will suffice in order to found a consistent philosophical anthropology, as in modern natural law. But even this small operationalisation of the anthropological requirements of Luhmann's sociology points in my view towards the actual existence of universalistic philosophical underpinnings without which sociological concepts simply cannot do their job - and thence the sociological enterprise becomes increasingly meaningless. Luhmann does conceptualise communication as an autonomous and emergent domain, but the ultimate fact that there is no society without human beings makes it necessary for the concept of communication to be compatible with this universalistic anthropology. Socio-cultural variation and the emergence of communication can be regarded as twin sociological facts because they are mutually reinforcing in terms of trying to grasp the specificity of the social as an autonomous domain. In relation to experiences of sociocultural difference and normative variation, on one side, social theory's claim to universalism pushes us to think in terms of the active and creative role of human conduct as a fundamental fact that is in need of explaining: people do things differently while pursuing their goals and that is a capacity which cannot be taken away without fundamentally altering that we really are as human beings. In relation to the emergent character of communication, on the other side, social theory's claim to universalism speaks of its unpredictability in terms of contingency - things can always be otherwise - and autonomy, once activated by inner motives and drives, what takes place in society has little to do with what was originally intended. Insofar as diversity, disagreement, unpredictability and autonomy are all key aspects of our sociological explanations, it is my contention that their actual universality is more fundamental than their exhaustive empirical register.

Our sociological concepts must, and indeed have tended to be, strong enough to uphold the kind of universalistic orientation that is actually in operation both descriptively (there is diversity and social trends cannot really be predicted) and normatively (these two facts themselves

argument emphasises those attributes that make us one and the same species and without the help of which our social scientific concepts just cannot perform their main task: allowing us to understand social relations as varied and emergent.

${ }^{11}$ I have adopted but freely modified these attributes from Steven Lukes' (2008) discussion of Martha Nussbaum's work. My thanks to Aldo Mascareño for pointing out to me this way of framing this issue. 
prove that we are part of one and the same human species). In turn, this means that the burden of the proof lies no so much in the affirmation of this universalistic orientation of sociological concepts but is passed on to those who seek to derive radically relativist consequences from the mere empirical register of diversity and unpredictability. An admittedly more troublesome consequence of this, however, seems to be that some conception of humanity, human beings and even human nature may still be needed (or surreptitiously in use) for explaining the type of qualities all human beings do possess (even if they are partially unknown and ultimately unknowable). In order to fully understand all the religious, ethnic and socio-cultural variation to be found in modernity, modern social theory is pushed to find always better justifications for universalistic propositions on the ultimate unity of the human species and fundamental equality of all human beings. It is only in so doing that it becomes adequately equipped to commence its long journey towards trying to understand the social. Yet social theory's long-term research agenda the empirical account of the rise and main features of modern social life — depends upon a claim to universalism whose contentious origins lie in the tradition of natural law. The founding concepts and theoretical strategies of social theory came into being with a view to understanding the social as such (i.e. without restriction of time, place or culture).

\section{Conclusion}

This paper sought to offer an argument on the need to think about the universalistic underpinnings of our social scientific concepts. I concentrated on the sociological programme of functional differentiation, and on Luhmann's sociology in particular, because it has had permanent commitment to descriptive universalism while at the same time it has tried to avoid normative consequences being attached to these intellectual pledges. With Luhmann, as it were, I argued that descriptive universalism is essential for sociological arguments on differentiation to work. But against Luhmann I thought to demonstrate that a commitment to descriptive universalism does carry normative implications with it. As we explored the interrelationships between both types of universalism, finally, social theory's debt to natural law was also being unpacked.

Because differentiation processes are inextricably connected to socio-cultural variation and the emergence of the social, they reinforce our understanding of the social as an autonomous realm. The universality of differentiation processes may work as an antidote against some of social theory's untenable propositions: its nationalistic bias, its materialistic reductionism or indeed its normative naïveté. Questions about social and functional differentiation are, quite rightly, central to our current understanding of world society and global modernity. Yet for them to realise their potential, we still need to address more fully refer to the normative underpinnings as well as implications of thinking in terms of differentiation processes. Sociologically relevant notions of differentiation require of strong universalistic presuppositions that speak of the unity of the human species.

\section{References}

Albert, M. 2007. 'Globalization theory': Yesterday's fad or more lively than ever? International Political Sociology, 1(2), 165-182.

Albert, M. 2009. Globalization and world society: A reply. International Political Sociology, 3(1), 126-128.

Arendt, H. 1958. The Origins of Totalitarianism. New York: Meridian Books.

Bauman, Z. 1998 Globalization. Cambridge: Polity Press. 
Beck, U. 2000 What is Globalization? Cambridge: Polity Press.

Beck, U. 2006. Cosmopolitan Vision. Cambridge: Polity Press.

Bendix, R. 1967. Tradition and modernity reconsidered. Comparative Studies in Society and History 9(3), 292-346.

Bloch, E. 1996. Natural Law and Human Dignity. Massachusetts: MIT Press.

Bohman, J. 2004. Republican cosmopolitanism. Journal of Political Philosophy, 12(3), 336-352.

Bourdieu, P. 1977. Outline of a Theory of Practice. Cambridge: Cambridge University Press.

Bourdieu, P. 1993. Sociology in Question. London: Sage.

Burnkhorst, H. 2005. Solidarity. From Civic Friendship to a Global Legal Community. Cambridge, Mass.: The MIT Press.

Castells, M. 1996. The Rise of the Network Society. Oxford: Blackwell.

Chernilo, D. 2002. The theorisation of social coordinations in differentiated societies. The theory of generalised symbolic media in Parsons, Luhmann and Habermas. British Journal of Sociology, 53(3), 431-449.

Chernilo, D. 2007. A social theory of the nation-state: The political forms of modernity beyond methodological nationalism. London: Routledge.

Chernilo, D. 2012a. Cosmopolitanism and the question of universalism, in Routledge Handbook of Cosmopolitan Studies, edited by G. Delante. London, Routledge, 47-59.

Chernilo, D. 2012b. Cosmopolitanism in social theory: An ambivalent defence, in European Cosmopolitanism in Question, edited by A. Krossa and R. Robertson. London: Palgrave, in press.

Chernilo, D. 2013a. The Natural Law Foundations of Modern Social Theory. Cambridge: Cambridge University Press.

Chernilo, D. 2013b. Jürgen Habermas: Modern social theory as postmetaphysical natural law. Journal of Classical Sociology, in press.

Connell, R. 2007. Southern Theory. Cambridge: Polity Press.

d'Entrèves, A. 1970. Natural Law. London: Hutchinson.

Douzinas, C. 2000. The End of Human Rights. Oxford: Hart.

Durkheim, E. 1965. The Elementary Forms of the Religious Life. New York: The Free Press.

Durkheim E. 1982. The Rules of Sociological Method. New York: The Free Press.

Durkheim, E. 1984. The Division of Labour in Society. London: Macmillan.

Gierke, O. 1927. Political Theories of the Middle Ages. Cambridge: Cambridge University Press.

Glacken, C. 1967. Traces on the Rhodian Shore. Nature and culture in Western though from ancient times to the end of the eighteenth century. Los Angeles, Ca.: University of California Press.

Fine, R. 2002 Democracy and the Rule Law. Caldwell, NJ: The Balckburn Press.

Fine, R. 2007. Cosmopolitanism. London: Routledge.

Fischer-Lescano, A. 2012. Critical systems theory. Philosophy and Social Criticism, 38(1), 3-23.

Giddens, A. 1993 New Rules of Sociological Method. Stanford: Stanford University Press.

Haakonssen, K. 1996. Natural Law and Moral Philosophy. Cambridge: Cambridge University Press.

Habermas, J. 1984. The Theory of Communicative Action. Vol. 1. London: Heinemann.

Habermas, J. 1987. The Theory of Communicative Action. Vol. 2. Boston: Beacon Press.

Habermas, J. 1996. Between Facts and Norms. Cambridge, Mass.: The MIT Press.

Habermas, J. 1998. The Inclusion of the Other. Cambridge, Mass.: The MIT Press.

Habermas. J. 2001. The Postnational Constellation. Cambridge: Polity Press.

Hegel, G. 1975. Natural Law. Philadelphia, Pa.: University of Pennsylvania Press.

Hegel, G. 1991. The Philosophy of Right. Cambridge: Cambridge University Press.

Kant, I. 1996. The Metaphysics of Morals. Cambridge: Cambridge University Press. 
Kant, I. 1997. Groundwork of the Metaphysics of Morals. Cambridge: Cambridge University Press.

Kessler, O. 2009. Toward a sociology of the international? International relations Between anarchy and world society. International Political Sociology, 3(1), 87-108.

Koskenniemi, M. 2009. Miserable comforters: International relations as new natural law. European Journal of International Relations, 15(3), 395-422.

Latour, B. 2000. Reassembling the Social. Oxford: Oxford University Press.

Luhmann, N. 1977. Generalized media and the problem of contingency, in Explorations in the General Theory in Social Science. Essays in Honor of Talcott Parsons, edited by J. Loubser, R. Baum, A. Effrat and V. Lidz. New York: The Free Press, 507-532.

Luhmann, N. 1990. Essays on Self-reference. New York: Columbia University Press.

Luhmann, N. 1994. 'What is the Case?' and 'What Lies Behind it?' The two sociologies and the theory of society. Sociological Theory, 12(2), 126-139.

Luhmann, N. 1995. Social Systems. Stanford: Stanford University Press.

Luhmann, N. 1997. Die Gesellschaft der Gesellschaft. Frankfurt: Suhrkamp.

Luhmann, N. 2008. Are there still indispensable norms in our society. Soziale Systeme 14(1), 1837.

Luhmann, N. 2010. Los derechos fundamentales como institución: Aportación a la sociología política. México D.F.: Universidad Iberoamericana.

Lukes, S. 2008. Moral Relativism. London: Profile books.

Marx, K. 1975. Early Writings. London: Penguin.

Marx, K. and Engels, F. 1974. The German Ideology. London: Lawrence \& Wishart.

Mascareño, A. and Chernilo, D. 2009. Obstacles and perspectives of Latin American sociology: Normative universalism and functional differentiation. Soziale Systeme, 15(1), 72-96.

Montesquieu, C. 1990. The Spirits of the Laws. Cambridge: Cambridge University Press.

Mouzelis, N. 1999. Modernity: A non-European conceptualization. British Journal of Sociology, 50(1), 141-59.

Parsons, T. 1961. An outline of the social system, in Theories of Society, edited by T. Parsons, E. Shills, K. Naegele and J. Pits. New York: The Free Press, 30-79.

Parsons, T. 1967a. Durkheim's contribution to the theory of integration of social systems, in Sociological Theory and Modern Society, edited by T. Parsons. New York: The Free Press, 334.

Parsons, T. 1967b. Evolutionary universals in society, in Sociological Theory and Modern Society, edited by T. Parsons. New York: The Free Press, 490-520.

Parsons, T. 1968. The Structure of Social Action. New York: The Free Press.

Robertson, R. 2009. Differentiational reductionism and the missing link in Albert's approach to globalization theory. International Political Sociology, 3(1), 119-122.

Rommen, H. 1998. The Natural Law: A Study in Legal and Social History and Philosophy. Indianapolis: The Liberty Fund.

Rorty, R. 2009. Contingency, Irony, and Solidarity. Cambridge: Cambridge University Press.

Rosenberg, J. 2005. Globalization theory: A post mortem. International Politics, 42, 2-74.

Rosenberg, J. 2006. Why is there no international historical sociology? European Journal of International Relations, 12(3), 307-340.

Rosenberg, J. 2010. Basic problems in the theory of uneven and combined development. Part II: Unevenness and Political Multiplicity. Cambridge Review of International Affairs, 23(1), 156189.

Rousseau, J. 1993. The Social Contract and Discourses. London: Everyman.

Schluchter, W. 1981. The Rise of Western Rationalism. Max Weber's Developmental History. Los Angeles: University of California Press. 
Scholte, J. 2000. Globalization. A Critical Introduction. London: Palgrave.

Schneewind, J.B. 1998. The Invention of Autonomy. A History of Modern Moral Philosophy. Cambridge: Cambridge University Press.

Shaw, M. 2000. Theory of the Global State. Cambridge: Cambridge University Press.

Simmel, G. 1909. The problem of sociology. American Journal of Sociology, 15(3), 289-320.

Skinner, Q. 1998. Liberty Before Liberalism. Cambridge: Cambridge University Press.

Smith, A. 1974. The Wealth of Nations. London: Penguin.

Smith, A. D. 1983. Nationalism and classical social theory. British Journal of Sociology, 34(1), 1938.

Spencer, H. 1961 The Study of Sociology. Belford: Ann Arbor.

Stichweh, R. 2008. Strangers, Inclusions and Identities. Lecture delivered in the doctoral programme at the University Alberto Hurtado, October.

Tönnies, F. 2001. Community and Civil Society. Cambridge: Cambridge University Press.

Touraine, A. 1977. The Self Production of Society. Chicago: The University of Chicago Press.

Tuck, R. 1981. Natural Rights Theories: Their Origin and Development. Cambridge: Cambridge University Press.

Turner, B.S. 2006a. Classical sociology and cosmopolitanism: A critical defence of the social. British Journal of Sociology, 57(1), 133-155.

Turner, B.S. 2006b. Vulnerability and Human Rights. Pennsylvania: Pennsylvania State University Press.

Voegelin, E. 1962. World-empire and the unity of mankind. International Affairs, 38(2), 170-188.

Weber, M. 1949. The Methodology of the Social Sciences. New York: The Free Press.

Weber, M. 1975. Roscher and Knies: The Logical Problems of Historical Economics. New York: The Free Press.

Weber, M. 1970. Religious Rejections of the World and their Directions, in From Max Weber. Essays in Sociology, edited by H. Gerth and C.W. Mills. London: Routledge and Kegan Paul, 323-361.

Wimmer, A. and Schiller, N. 2002. Methodological nationalism and beyond: Nation-state building, migration and the social sciences. Global Networks, 2(4), 301-334.

Yack, B. 1997. The Fetishism of Modernities. Epochal Self-Consciousness in Contemporary Social and Political Thought. Notre Dame, In.: University of Notre Dame Press.

\section{Acknowledgements}

An early version of this paper was prepared for the workshop on '(Functional) Differentiation in International Relations and Sociology' at the Wissenschaftszentrum Berlin in December 2009. My thanks to Mathias Albert, Barry Buzan and Michael Zürn for their invitation to take part in this workshop. I am extremely grateful to Aldo Mascareño for very helpful comments, suggestions and criticisms. 